\title{
The Effect of Enterprise Risk Management on Financial Distress
}

\author{
Nur Khalizah Luthfiyanti \\ Universitas Trilogi \\ Lely Dahlia \\ Universitas Trilogi
}

\begin{abstract}
Lately, the retail industry has been suffering financial performance problem caused by some factors, such as the trade competition with online trading. Companies in the retail industry sector had to handle this risk to minimize further financial performance problem. This study aims to determine the impact of the implementation of enterprise risk management in avoiding financial distress. This study used binary logistic regression for tool analysis. The sample of this study involved 21 retail companies listed on the Indonesia Stock Exchange from 2013 to 2017. The sample has been selected using a purposive random sampling method. Variable control, namely, liquidity, profitability, leverage, and company size, are included. The result of the study indicates that enterprise risk management implementation was found affecting financial distress
\end{abstract}

Keywords: Enterprise Risk Management, Financial Distress, Binary Logistic Regression, Retail companies, Indonesia Stock Exchange

\section{Introduction}

In 2017, the majority of retail industry experienced a hard time for survival. Declining financial performance and closing outlets are an indication to figure out severe condition faced by the retail industry (Idris , 2017). Recognized retails companies such as Lotus, Ramayana, Matahari, Debenhams, and 7-Eleven are some example that closed their outlets n 2017. According to the Indonesia Retail Employers Association, around 10\% of employees of retail companies were laid off during 2017. According to Dwijayanti (2010), financial distress will occur in a company if there is a lay off of labour. Some factors that cause the decline in retail companies' finances are the decrease in customer's purchasing power and the shifting of customer's shopping patterns from offline to online. It is undoubtedly a harmful impact on the company because it triggers financial distress. According to Fahmi (2013), the definition of financial distress is a stage of decline in financial conditions that occurred before bankruptcy or liquidation.
Financial distress can be avoided by using sources effectively, efficiency, and proper management. Indication of proper management if the company has risk management. A business organization is closely associated with operational risk, strategic risk, technological risk, and competitive risk. It is, therefore, Enterprise Risk Management (ERM) is needed to manage corporate risk. According to Hery (2015), Enterprise Risk Management is a systematic and ongoing process that is designed and run by management to provide adequate confidence that all risks that have the potential to have a negative impact have been managed in such a manner in accordance with the company risk tolerance level. Effective enterprise risk management minimizes the risk that potentially harms the company and increases long-term competitive advantage (Saptiti, 2013).

Companies that can not manage their risk well will adversely impact on their financial performance, and it potentially causes financial distress. Brigham \& Ehrhardt (2014) argue that the reason companies must manage their risk 
exposures is to avoid financial distress. A study conducted by the Center for Risk Management Study reveals that the implementation of ERM in Indonesian companies is still low. Some companies experience disruption to the company's financial condition due to the lack of implementation of ERM. Every company does not want to experience financial distress so that the risk must be managed well to avoid financial distress. The purpose of this study is to determine whether risk management can mitigate financial distress.

\section{Literature Review}

\section{Signalling Theory}

Signalling theory is one of the theories underlying the problem of information asymmetry. According to Brigham \& Houston (2010), a signal is an action taken by the company's management that allows investors to have an impression about the company. Implementation of good corporate governance in order to create a good reputation so that it can increase the value of the company is an example of how signalling theory work (Andarini \& Januarti, 2010). One of the signals in implementing corporate governance issued by companies is risk management disclosure.

\section{Enterprise Risk Management}

According to COSO, enterprise risk management (ERM) is a process, which is carried out by a board of commissioners/supervisors, management (board of directors) and other personnel, which is applied in strategy setting and is applied throughout the company designed to identify potential events that can affect the company and manage those risks within the company, to rationally guarantee the achievement of company goals (Moeller, 2011). COSO Enterprise Risk Management-Integrated Framework consists of eight components which connected to each other:

1. Internal Environment

The internal environment is a base to how the risk is identified and managed by the company, include the philosophy of company risk management and risk appetite and also the operational environment of the company.

2. Goal Setting

The goal should exist before the management identifies potential events that can influence the company's achievement. Corporate risk management ensures that the management has a process to determine goals and the chosen goals support and harmonize the entity mission and be consistent with risk appetite.

3. Event Identification

Internal and external events that influence the company's goal must be identified, distinguishing the risk and the opportunity. Opportunities are channelled back to the management strategy or goal-setting process.

4. Risk Assessment

Risk is analyzed by considering the possibilities and the impact as a base to determine how the risk must be managed. Risk is assessed based on inherent and residual.

5. Risk Response

Management chooses the risk in the form of avoiding, accepting, reducing, or sharing risks, managing a series of actions to align risk develops choosing to align risks by increasing the risk with risk tolerance and risk appetite of the company.

6. Control Activities

The policy and the procedure are made and applied to help and ensures risk response is implanted effectively.

7. Information and Communication

The relevant information is identified and communicated that possibly, whole corporate management received the information to implement their responsibility.

8. Monitoring

The overall risk management of the company is monitored and modified according to company needs. Monitoring is achieved through ongoing management activities, separate evaluations, or both.

The effectiveness of ERM can be identified by assessing the existence and functioning of the eight components (Bediako, 
2014). Adopting integrated risk management is one of the strategies to avoid the occurrence of financial distress. Integrated risk management enables companies to identify risk exposures. Therefore, the company can determine strategies to deal with the impact of the risks (Koeswara \& Harjito, 2016). Critical factors for successful implementation of ERM are executive support, the development of an intelligent culture in dealing with risks, incorporating risk into strategies, defining risk appetite early, considering building ERM programs at certain stages, focusing initially at some agreed highlevel risks, using initial work as a platform for ERM development, and developing initial monitoring processes (Marchetti, 2012)

\section{Financial Distress}

Financial difficulties can be temporary and not so severe, but if left untreated can develop into problems that are not solvable (Hanafi \& Halim, 2016). Financial distress condition happens before the company bankrupt, and this condition caused the company unable to pay the costs that will be due. According to Kordestani, Biglari, \& Bakhtiari (2011), the stages of bankruptcy are described as follows:

1. Latency. In the latency stage, Return on Assets (ROA) will decrease.

2. Shortage of Cash. In this stage, the company does not have enough cash resources to meet current obligations, although it may still have a healthy level of profitability.

3. Financial Distress. Financial difficulties can be considered as a financial emergency, which is nearing bankruptcy.

4. Bankruptcy. If the company can not cure the symptoms of financial distress, then the company will go bankrupt.

Financial distress can be caused by internal and external factors of the company. According to Lizal (2002), there are three factors that cause financial distress, namely allocation resources, financial structure and governance. First, Financial distress occurs when the allocation of resources is not right. Secondly, financial distress is characterized by an incorrect financial structure and causes liquidity constraints. Third, financial distress according to the corporate governance model is when a company has the right asset structure and good financial structure but is poorly managed.

\section{Research Hypothesis}

Brigham \& Ehrhardt (2014) suggest that companies must manage their risk exposures in order to avoid financial distress. If a company can handle the risks well, the company have a chance to avoid losses. Companies that succeed in implementing effective enterprise risk management (integrative) have a more competitive long-term advantage compared to companies that manage and monitor risks partially (Saptiti, 2013). Therefore, the hypothesis is proposed as follows:

H1: Enterprise Risk Management has a negative effect on the company's financial distress.

Leverage is a company's ability to meet its obligations, both current and long-term obligations when the company is liquidated (Kasmir, 2012). Companies with high leverage mean most of their assets are financed by debt and capital. Therefore, the company will have a high financial risk because of severe financial difficulties that make high leverage to finance their activity. Therefore, the hypothesis is proposed as follows:

$\mathrm{H} 2$ : Liquidity has a negative effect on the company's financial distress

Profitability is an indication that the company uses its assets and manages its operations efficiently (Ross, Westerfield, Jordan, \& Firer, 2013). It can be concluded that profitability is a measure of a company's ability to making a profit. Companies that have high profitability are less likely to experience financial difficulties. Therefore, the hypothesis is proposed as follows:

H3: Profitability has a negative effect on the company's financial distress

Financial distress starts with the company's inability to fulfil its debt, especially short-term debt (Fahmi, 2013). The company that can finance and fulfils its short term debt will 
experience less financial distress. Therefore, the hypothesis is proposed as follows:

H4: Leverage has a positive effect on the company's financial distress.

Firm size is a measure of the scale of a company ( Titman and Wessels (Hendriani, 2011). The company with a high total asset will be more comfortable to diversify and tend to be less bankrupt (Aryadi, 2018). Therefore, the hypothesis is proposed as follows:

H5: Company size has a positive effect on the company's financial distress

\section{Methodology}

\section{Sample and Data}

Sample of this study is the retail companies listed on the Indonesian Stock Exchange (IDX) from 2013-2017. The data is generated from the financial statement that includes information disclosure of Enterprise Risk Management. The population of this study is retail companies listed on the Stock Exchange, with a total of 27 companies. The sample was taken by using a purposive sampling method, and 21 retail companies were selected.

\section{Operational Variable}

Enterprise Risk Management in this study is measured by using eight dimensions and 108 criteria based on the COSO ERM Framework. Effectiveness of ERM can be identified by assessing the existence and functioning of the eight components COSO ERM (Bediako, 2014). Every disclosure of one item ERM will be given a score of 1 and 0 if the item is not disclosed and the next score of each item will be added up to get the total score of disclosure on each company.
The ERM Retrieval Index is obtained from calculations:

$$
E R M D I=\frac{\text { Number of items disclosed }}{108 \text { disclosure items }}
$$

Financial distress in this study is measured by the Altman Z-score method. Z score bankruptcy analysis is used to predict the level of the bankruptcy of a company by calculating the value of several ratios and then included in a discriminant equation (Gamayuni, 2011). The Altman Z-score is expressed in a linear equation consisting of 4 coefficients " $T$ " representing specific financial ratios, namely:

$Z=6,56 T 1+3,26 T 2+6,72 T 3+1,05 T$

Where:

$\mathrm{T} 1$ = working capital / total assets

$\mathrm{T} 2=$ retained earnings $/$ total assets

$\mathrm{T} 3=$ earnings before interest and tax / total assets $\mathrm{T} 4=$ market value of equity/book value of total liabilities

Altman sets the Z-Score above 2.60 as the category of non-bankrupt companies. Meanwhile, companies with a Z-Score below 2.60 is categorized as bankrupt companies. Companies that experience financial distress will be given a value 1(one), and non-distress companies will be given value 0 (zero).

\section{Control Variable}

The existence of control variables will help in interpreting the purpose of the overall relationship (Neuman, 2014). The purpose of using control data is to find out whether the data from the object under study has different characteristics (or has specific characters). The control variables used are leverage, profitability, company size and liquidity. The measurement of the control variable is presented in Table 1. 
Table 1. Control variable measurement

\begin{tabular}{|l|l|l|}
\hline \multicolumn{1}{|c|}{ Control Variable } & \multicolumn{1}{c|}{ Indicator } & \multicolumn{1}{c|}{ Formula } \\
\hline Leverage & Debt to Equity Ratio & Total Debt / Total Common Equity \\
\hline Profitability & Return on Asset & Earning After Tax / Total Assets \\
\hline Company Size & Total Aset & Logarithms Natural Total Assets \\
\hline Liquidity & Current Ratio & Current Assets / Current Liabilities \\
\hline
\end{tabular}

\section{Data Analysis Method}

In this study, the hypothesis is tested using binary logistic regression with STATA13. The reason for using binary logistic regression is because of the dependent variable category is a binomial dummy variable ( 1 and 0 ). Prediction model to the dependent variable is a financial distress and the enterprise risk management for the independent variable. Meanwhile, the control variable is leverage, profitability, liquidity, and company size. The regression model used to test the hypothesis in this study is:

$$
\operatorname{Ln}\left(\frac{P_{i}}{1-P_{i}}\right)=\beta_{0}+\beta_{1} E R M D_{i t}+\beta_{2} C R_{i t}+\beta_{3} R O A_{i t}+\beta_{4} D E R_{i t}+\beta_{5} S I Z E_{i t}+u_{i}
$$

$\operatorname{Ln}\left(\frac{P_{i}}{1-P_{i}}\right) \quad$ :logarithm of the probability of a company experiencing financial distress

$\beta_{i}$

ERM : Company risk management disclosure index i time $\mathrm{t}$

$\mathrm{CR} \quad$ : Company liquidity i time $\mathrm{t}$

ROA : Company profitability i time $t$

DER : Leverage company $i$ time $t$

Size $\quad$ : Size of company i time $t$

\section{Results and Discussions}

\section{Hypothesis Testing Model 1}

In this study, researchers tested data three times because the benefits of implementing enterprise risk management cannot be felt immediately. According to (Saptiti, 2013) that the benefits of ERM were felt in the long run so that researchers conducted testing three times using ERM data that has been going backwards for two years.

Table 2. Result of regression model 1

\begin{tabular}{|l|l|l|l|}
\hline \multicolumn{4}{|l|}{ Prob $>$ chi2 $=0.0005$, Observation $=105$} \\
\hline Variable & P-Value & Coefficient & Odds Ratio \\
\hline ERM & 0.030 & 36.473 & 6.920 \\
\hline CR & 0.428 & -0.442 & 0.643 \\
\hline ROA & 0.001 & -17.342 & 2.940 \\
\hline DER & 0.192 & 0.498 & 1.646 \\
\hline SIZE & 0.747 & 0.247 & 1.280 \\
\hline Konstanta & 0.163 & -32.538 & 7.390 \\
\hline
\end{tabular}


The constant-coefficient in this study shows a value of $-32,538$ (Mendenhall, 2011) states that negative does not need to be interpreted because they show unreasonable results. The coefficient value in logistic regression must be changed into the anti-log to be interpreted. From the results of these tests, the logistic regression equation can be formed, as follows:

$$
\begin{aligned}
F D=-32,538 & +36,473 E R M_{i t}-0,442 C R_{i t} \\
& -17,342 R O A_{i t}+0,498 D E R_{i t} \\
& +0,247 S I Z E_{i t}+u_{i}
\end{aligned}
$$

The overall test results obtained with the value of probability > chi $2=0.0005$ smaller than the significance level of 0 . It means that a confidence level of $90 \%$, can be concluded that there is at least one independent which is agreed upon the dependent variable. Partially, there is an independent variable (enterprise risk management) that affects the dependent variable (return on assets) because it has a p-value less than the significance level of the test of 0.1. ERM variable shows that the $p$-value of 0.030 is smaller than the significance level of 0.1 so that the enterprise risk management hypothesis has a negative effect on financial distress. However, the coefficient value of the ERM variable shows a value of 36.473 which means there is an anomaly in this study. The variable current ratio has a p-value of 0.428 greater than alpha 0.1 , which shows that liquidity measured by the current ratio is not affected financial distress. It means hypothesis 2 is rejected. The return on asset variable has a p-value of 0.001 and a coefficient of $-17,342$ and an odds ratio of 2.940 . The ROA variable has a negative effect on financial distress because it has a p-value below the significance level of 0.1 and the coefficient with a negative sign. Return on asset variable has a p-value of 0.001 and a coefficient of $-17,342$ and an odds ratio of 2.940. ROA variable has a negative influence on financial distress because it has a p-value below the significance level of 0.1 and a coefficient with a negative sign. If the company increases a one point percentage return on assets, then financial distress will decrease by 17,342 with other assumptions constant. The odds ratio on the variable return on assets is 2,940 . It means that if the return on assets decreases, on average, around 2.940 times the probability that the company will experience increased financial distress. DER variable has a p-value of 0.192 higher than the significance level of 0.1 , so the fourth hypothesis, which states the ratio of debt to positive equity to financial distress, is rejected. The coefficient value of the firm size variable shows a positive value. The results contradict to the study hypothesis, which formulates that company size has a negative direction on financial distress. There is a possibility that the size of the company has a positive direction on financial distress because a big size company has many assets that must be depreciated and expenses that need to be borne by the company. Therefore the larger the size of the company, the higher the burden borne by the company.

\section{Hypothesis Testing Model 2}

In testing of the second model hypothesis, disclosure data used in this study is backward one year (2012-2016). Meanwhile, CR, ROA, DER and size variable still data on 2013-2017. The result of the second hypothesis is:

Table 3. Result of regression model 2

\begin{tabular}{|l|l|l|l|}
\hline Prob $>$ Chi2 $=0.0001$, Observation $=105$ & Coeficient \\
\hline Variable & P-Value & 24.354 & Odds Ratio \\
\hline ERM & 0.087 & -0.124 & 3.770 \\
\hline CR & 0.753 & -13.148 & 0.883 \\
\hline ROA & 0.004 & 0.314 & 1.950 \\
\hline DER & 0.347 & -0.096 & 1.369 \\
\hline SIZE & 0.922 & -13.697 & 0.908 \\
\hline Konstanta & 0.661 & & 1.130 \\
\hline
\end{tabular}


The coefficient value in logistic regression must be changed into the anti-log to be interpreted, as follows:

$$
\begin{aligned}
F D=-13,697 & +24,354 E R M_{i t-1} \\
& -0,124 C R_{i t}-13,148 R O A_{i t} \\
& +0,314 D E R_{i t}-0,096 S I Z E_{i t} \\
& +u_{i}
\end{aligned}
$$

The overall test that is indicated by the value of Prob> Chi2 $=0.0001$ is smaller than the significance level of 0,1 . It shows that there are at least one of the variables ERM, CR, ROA, DER, and size that affect the variables' financial distress by $90 \%$ confidence level. ERM variable has a p-value of 0.087 smaller than the significance level of 0.1 and a coefficient value of 24,354 . Because of it, the hypothesis of this study is accepted, but the coefficient value of the ERM variable shows a positive value inversely proportional to the hypothesis so that there is an anomaly in this study. The liquidity variable measured by the current ratio shows that the $\mathrm{p}$ value is greater than alpha which is 0.753 so that the company's liquidity ratio hypothesis has a negative effect on financial distress. The $\mathrm{p}$-value of the variable return on assets is 0.004 smaller than the significance level of 0.1 . It means that the company's profitability ratio as measured by return on assets has a negative effect on financial distress.

\section{Hypothesis Testing Model 3}

In testing the third model hypothesis, ERM used in this study is backward one year (2015-2011), but the control and dependent variables in this third test still use the data for 2017-2013. Following are the results of testing the third model hypothesis:

Table 4: Result of regression model 3

\begin{tabular}{|l|l|l|l|}
\hline Prob $>$ Chi2 $=0.0000$, Observation $=105$ & Odds Ratio \\
\hline Variable & P-Value & Coeficient & 4.110 \\
\hline ERM & 0.000 & 38.256 & 0.617 \\
\hline CR & 0.150 & -0.483 & 0.002 \\
\hline ROA & 0.056 & -6.051 & 1.267 \\
\hline DER & 0.323 & 0.237 & 0.329 \\
\hline SIZE & 0.120 & -1.109 & 10317 \\
\hline Konstanta & 0.652 & 9.242 & \\
\hline
\end{tabular}

Based on the results of table 4, the logistic regression equation can be formed, as follows:

$$
\begin{aligned}
F D=9,242+ & 38,256 E R M_{i t-2}-0,483 C R_{i t} \\
& -6,051 R O A_{i t}+0,237 D E R_{i t} \\
& -1,109 S I Z E_{i t}+u_{i}
\end{aligned}
$$

The table above shows the overall test results that can be seen from the value of Prob> Chi2 $=0.0000$, which is smaller than the significance level of 0.1 . It means that there are at least one of the variables ERM, CR, ROA, DER, and size that affect the financial distress variable by a $90 \%$ confidence level. Partially, there are independent variables (enterprise risk management) that influence the dependent variable (return on assets) because they have a pvalue less than the significance level of 0.1 .
The coefficient of the ERM variable shows 38,256 , inversely proportional to the study hypothesis, which shows that ERM has a negative effect on financial distress, so there is an anomaly in this study. The test results show that the current ratio variable has a $p$-value of 0.483 greater than alpha 0,1 . It is shown that liquidity measured by the current ratio has no effect on financial distress, which means hypothesis 2 is rejected. The return on asset variable has a p-value of 0.056 , a coefficient of -6.051 and an odds ratio of 0.002. ROA variable has a negative effect on financial distress because it has a p-value below the significance level of 0.1 and a coefficient with a negative sign. Therefore, if the company increase one percentage point of return on assets, then financial distress will decrease by 6.051 with other assumptions constant. Odds ratio on the 
variable return on assets is 0.002 , which means that if the return on assets decreases, on average, about 0.002 times the probability that the company will experience financial distress increases. The DER variable has a p-value of 0.323 higher than the significance level of 0.1 so that the fourth hypothesis, which states that the debt to equity ratio has a positive effect on financial distress is rejected. The table above shows the p-value of the firm size variable is 0.120 greater than the significance level of 0.1 so that the company size variable measured by the natural logarithm of the company's total assets has no effect on financial distress.

\section{Discussion}

Enterprise Risk Management and Financial Distress

The result shows that from the three models tested; there is an effect of enterprise risk management on financial distress because the pvalue of the ERM variable is smaller than alpha 0.1 . This is in line with the theory used (Brigham \& Ehrhardt , 2014) about the reason why companies must manage their risk exposures well, one of the reason is to avoid the occurrence of financial distress and the results of the study (Lai \& Samad, 2011) namely the application of risk management can reduce costs of financial distress. The results of this study indicate the positive effect of enterprise risk management on financial distress, because of the legal basis for the implementation of risk management in Indonesia is still weak so that the application of enterprise risk management in companies in Indonesia is also still low. Government regulation that implements risk management in companies is the Regulation of the State Minister for StateOwned Enterprises Number: Per-01 /MBU/2011 Concerning the Implementation of Good Corporate Governance in State-Owned Enterprises Article 25: Directors, in every decision decisions/actions, must consider business risks and regulations issued by the Financial Services Authority (OJK) which outline the duties of the audit committee and internal audit, implicitly mentioning the need for risk management activities by issuers or public companies. The company manages its risk management because ERM is a form of good corporate governance, awareness of the importance of the benefits of ERM makes the company begin to improve the application of enterprise risk management. The company manages its risk management because ERM is a form of good corporate governance, awareness of the importance of the benefits of ERM makes the company begin to improve the application of enterprise risk management. In this study, ERM is measured by company disclosures based on 108 ERM COSO disclosures. The company discloses risk management as a form of good corporate governance disclosure and meets the PSAK No. 60 of 2010 concerning Disclosure of Financial Instruments so that users of financial statements know-how companies manage the risks faced. Every year the company's ERM disclosure continues to increase; it shows the company is also trying to improve the application of ERM in operational activities. Although the disclosure of ERM continues to increase every year, it can not prevent the company from financial distress, because what the company disclosed is not necessarily in accordance with the actual application in the company. Disclosure in the annual report can not give an idea of how much quality the implementation of ERM has been done by the company. ERM is a systematic and sustainable process; the impact of implementing ERM will be felt in the long run. So companies need to tighten and improve the quality of the implementation of ERM until the application of optimal enterprise risk management so that companies can feel the benefits in the future.

\section{The company's liquidity and financial distress}

The result shows that from the three hypotheses, the p-value of the current ratio variable is higher than the significance value of 0.1 , which means that company liquidity as measured by the current ratio has no effect on financial distress. It is happening because retail companies have current assets that are mostly stored in inventory accounts. The declining public purchasing power allows companies to make small profits because the company's inventory is not sold so that even though the company's liquidity ratio is high, the 
company does not have enough funds to operate and cannot avoid conditions of financial distress.

\section{Profitability ratios and financial distress}

Based on the testing table of models 1, model 2, and model 3, the return on asset variable both show a p-value smaller than the significance level of 0.1 . It means that the third hypothesis in this study is accepted because the profitability measured by returns on assets influence negatively towards financial distress. It is proven by the data in this study that shows that there are companies in the previous year included in the non-distress category, but on the following year, the company had a decline in profits and became a distress company category. Study data also shows the opposite result when a distressed company had an increase in profit; in the following year, the company becomes a nondistress category company. The results of this test are in line with the study (Kordestani, Biglari, \& Bakhtiari, 2011), the first stage of bankruptcy is the company's return on assets has decreased. If the company's return on assets is high, it shows that the company has efficiently used its assets to make a profit. These advantages minimize the possibility of companies experiencing financial distress.

\section{The company's leverage ratio and financial} distress

In this study, the ratio of financial leverage is measured by the debt to equity ratio. This ratio shows the proportion of equity and debt used to finance company assets. The test results of the three models show the p-value of the DER variable is higher than the significance level of 0.1 , which means that leverage, as measured by the debt to equity ratio, has no effect on financial distress. This study data shows several companies that are categorized as non-distress but have a high DER ratio because in the retail industry most of the company's debts are third party debts (as current debt), debts to third parties represent debts between companies and product suppliers. High third-party debt can indicate that the company's sales are also high so that the profits obtained are also high. By the profit, the company can avoid financial distress because it has sufficient funds for operational activities.

\section{Company size and financial distress}

The results of testing the three models show that the p-value of the firm size variable is higher than the level of significance so that the size of the company has no effect on financial distress. That is because according to (Rahayu \& Sopian, 2017) large companies that have substantial total assets can not be separated from substantial risks, such as economic risks, namely fluctuations in the exchange rate of the rupiah against the dollar, interest rates, and inflation rates, all of these things have a significant impact on the company's financial position. Companies that have substantial assets also have to bear significant expenses such as depreciation and operational expenses so that the profits obtained by the company will be small and affect the company's finances. So the company will continue to experience difficulties to pay off debts when due.

\section{Conclusion}

The conclusion of this study is that the application of Enterprise Risk Management affects Financial Distress. It is based on the result of the p-values of the three models from logistic regression shows smaller values than the significant level of 0.1. It means enterprise risk management of the retail company has been averagely disclosure amount to $63 \%$. Therefore it can explain that enterprise risk management has an effect on financial distress conditions. Enterprise risk management affects two years from before the company experienced financial distress. In this study, there is four control variable. They are liquidity which measured by current ratio, profitability measured by return on asset ratio, leverage which measured by debt to equity ratio and size of the company which measured by the natural logarithm of total assets. From the results of the data test, all three show the results of the p-value variable return on assets are smaller than the significant level of 0.1 . So the return on asset variable has a negative effect on 
financial distress, which means if the company experiences a decrease in return on assets, the probability of the company experiencing financial distress increases.

To increase the effectiveness of the implementation of ERM, companies can improve internal control and internal audit, because both are essential components in the implementation of ERM. Internal audits monitor how effectively the company assesses and manages risk. Companies can also form a management committee to achieve optimal implementation of corporate risk management because the critical component of a practical ERM function is the presence of a leader who is responsible for overall risk management. This process is usually held by the Chief Risk Officer (CRO). So companies can implement effective corporate risk management and build a robust risk management culture in the internal environment of employees who have strict policies because the internal environment is the basis of the ERM application. In addition to improving the quality of the implementation of corporate risk management, companies can also work with specialized companies that specialize in Corporate Risk Management or develop training programs for employees on implementing ERM.

The limitation of this study is the method of evaluating the application of corporate risk management through disclosures made by companies so that the conclusions are only based on statistical calculations. Cannot explain the actual condition of the company / Another limitation is this research sample. Samples are the only retail companies listed on the IDX with a study period of only five years. Therefore, further research is better to use direct methods such as interviews or direct observations, so the results will clearly show the actual conditions of the application of corporate risk management in the company that is the object. This research can also add companies from other industries.

\section{References}

AICPA, A. (2010). Enterprise Risk Management-The COSO Framework:A Primer and Tool for the Audit
Committee. Retrieved from ttps://www.google.co.id/?gws_rd=ssl\#q $=$ ERM+and+reliability+of+report ing.

Andarini, P., \& Januarti, I. (2010). Relationship between the Characteristics of the Board of Commissioners and the Company to the Disclosure of Risk Management Committee (RMC) in Go Public Companies in Indonesia. National Accounting Symposium CIII.

Aryadi, M. A. (2018). The Effect of Profitability, Liquidity, Leverage, and Firm Size on Financial Distress. eprints.perbanas.

Bediako, T. (2014). Enterprise Risk Management - Integrated Framework. ISACA'S IT Audit, Information Security \& Risk Insights Africa 2014. Africa.

Brigham, E., \& Ehrhardt, M. (2014). Financial Management: Theory and Practice 14th Edition. Ohio: South-Western Cengage Learning.

Brigham, E., \& Houston, J. (2010). Fundamentals of Financial Management (Ed. 11, Vol. 1). Jakarta, Indonesia: Salemba Empat.

Indonesia Stock Exchanges. (2019). Retrieved from https://www.idx.co.id/.

CRMS, I. (2018). Center Risk Management Studies. Retrieved from http://crmsindonesia.org:

/wcrmsindonesia.orgpcontent/uploads/2018/11/CRMSIndonesia-Survei-Nasional-ManajemenRisiko-2018.pdf

Dwijayanti, S. F. (2010). Causes, Impacts and Predictions of Financial Distress and Solutions to Overcome Financial Distress. Jurnal of Contemporary Accounting Vol.2 No.2, 191-205.

Fahmi, I. (2013). Corporate Financial Management and Capital Markets. Jakarta: Mitra Wacana Media.

Gamayuni, R. (2011). Altman Model Accuracy Analysis as a Tool for Predicting 
Bankruptcy (Empirical Study of Manufacturing Companies on the Indonesia Stock Exchange). Journal of Accounting and Finance Vol. 16, 158176, 158-176.

Gujarati, D., \& Porter, D. (2012). Basics of Econometrics Book 2 5th Edition. Jakarta: Penerbit Salemba.

Hanafi, D., \& Halim, P. (2016). Financial Statement Analysis Ed. 5th. Yogyakarta: UPP STIM YKPN.

Hendriani, N. G. (2011). The Effect of the Implementation of Corporate Governance to Avoid Financial Distress with Control Variables of Company Size and Funding Sources (Study on Listed Non-Financial Public Companies on the Indonesia Stock Exchange). Thesis.

Hery. (2015). Enterprise Risk Management. Jakarta: Grasindo.

Hosmer, D. (2013). Applied Logistic Regression $3 r d E d$. New York: John Wiley \& Sons, Inc.

Idris , U. (2017, November). Five Retail Outlets that Dropped in 2017. Retrieved from www.halomoney.co.id: https://www.halomoney.co.id/ritelmodern-yang-tumbang-di-2017

Indonesia, I. A. (2010). Exposure Draft PSAK No.60 Tahun 2010. Jakarta.

Jhames, C. H., \& Wachowicz.Jr, J. (2005). Fundamental of Financial Management, 12 Edition. USA: Prentice-Hall,Inc.

Kasmir. (2012). Financial Statement Analysis. Jakarta: PT. Raja Grafindo Persada.

Koeswara, A. I., \& Harjito, A. (2016). The Effect of Implementing Enterprise Risk Management on Financial Distress and Company Value. Indonesian Business Journal Vol. 3 Nomor 2, 185-198.

Kordestani, G., Biglari, V., \& Bakhtiari, M. (2011). Ability of Combinations of Cash Flow components to predict financial distress. Business: Theory and Practice, 277-285.

Lai, F.-W., \& Samad, F. (2011). Enterprise Risk Management Framework and The Empirical Determinants of Its Implementation.

Lizal, L. (2002). Determinants of Financial Distress: What Drives Bankruptcy in A Transition Economy? The Czech Republic Case. William Davidson Working Paper Number 451.

Marchetti, A. (2012). Enterprise Risk Management Best Practices: From Assessment to Ongoing Compliance. New Jersey: John Wiley \& Sons, Inc.

Mendenhall, W. (2011). A Second Course in Statistics: Regression Analysis [7th (Second Edition)]. USA: Prentice Hall.

Moeller, R. (2011). COSO Enterprise Risk Management: Establishing Effective Governance, Risk, and Compliance Process-2nd ed. USA: John Wiley \& Sons Inc.

Negara, M. N. (2011).Implementation of Good Corporate Governance. Jakarta.

Neuman, W. (2014). Social Research Methods: Qualitative and Quantitative Approaches. Boston-London: Allyn and Bacon.

Organizations, C. O. (2004). COSO.org. Retrieved from https://www.coso.org/Pages/ermintegratedframework.aspx.

Rahayu, W. P., \& Sopian, D. (2017). Effect of Financial Ratios and Firm Size on Financial Distress (Empirical Study on Food and Baverage Companies on the Indonesia Stock Exchange). STIE-STAN IM.

Ross, S., Westerfield, R., Jordan, B., \& Firer, C. (2013). Fundamentals of Corporate Finance. USA: McGraw-Hill.

Saptiti, A. (2013). Effect of Implementation of the Role of the Audit Committee and 
Enterprise Risk Management on Profit Quality. Thesis.

The ECIIA. (2013). Three Lines of Defence. Retrieved from http://www.eciia.eu/wpcontent/uploads/ 2013/09/OCV-3.2-3LD-Model.pdf. 